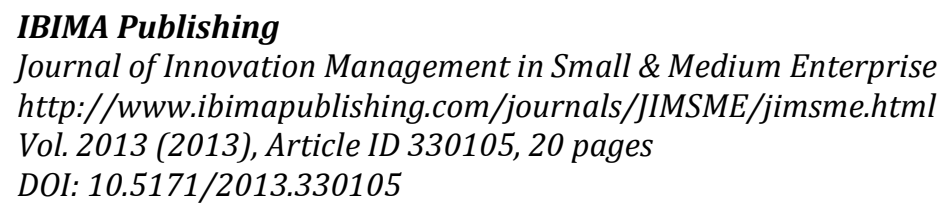

Research Article

\title{
Factors Contributing to Product Innovation in a Value Chain: Three Case Studies
}

\author{
Karen L. Orengo Serra and Nora B. Picón García \\ University of Puerto Rico, Rio Piedras, Puerto Rico \\ Received 30 September 2012; Accepted 2 December 2012; Published 27 February 2013 \\ Academic Editor: Susan Chin
}

\begin{abstract}
A company's capabilities can be categorized into business networks, knowledge acquisition, and strategic management. These capabilities are influenced by the constructs of the following orientations: EO (Entrepreneurial Orientation), MO (Market Orientation), LO (Learning Orientation) and TO (Technological Orientation). We propose an Innovation Conceptual Model to explain the relationship dynamics between innovation and capabilities as influenced by each orientation. The model is qualitatively applied to case studies on each key branch (manufacturer, distributor and retailer) of an international value chain in the professional aesthetics industry. Our findings show that innovation does not always have an effect on the achievement of a firm's goals. Variables such as production costs, in-house research, development and innovation, closed niche market, invasive aesthetic medicine, and commercial mass production help explain the observed dichotomies between innovation outcomes and the firm's goals.
\end{abstract}

Keywords: Aesthetics and beauty industry; innovation; strategic orientations; SMEs, value chain.

\section{Introduction}

The present study describes the dynamics of an innovation value chain in small and medium-sized firms (SMEs) through the analysis of firm capabilities and goals. To illustrate this dynamic we created an Innovative Conceptual Model (ICM) applying four traditional strategic orientations: market orientation (MO), entrepreneurial orientation (EO), learning orientation (LO), and technological orientation (TO) and the following business capabilities: business networks (BN), knowledge acquisition (KA), and technological capabilities (TC). The strategic orientations and business capabilities allow us to better understand the interaction between strategic orientations and innovation in the innovation value chain of the aesthetics industry represented in this study by one manufacturer, one distributor and one retailer. The exploratory nature of this work has led us to adopt the case study approach as our primary research method. The research did not attempt to measure or

Copyright (C) 2013 Karen L. Orengo Serra and Nora B. Picón García. This is an open access article distributed under the Creative Commons Attribution License unported 3.0, which permits unrestricted use, distribution, and reproduction in any medium, provided that original work is properly cited. Contact author: Karen $\mathrm{L}$. Orengo Serra E-mail: karenl.orengo@upr.edu

How to Cite this Article: Karen L. Orengo Serra and Nora B. Picón García, " Factors Contributing to Product Innovation in a Value Chain: Three Case Studies," Journal of Innovation Management in Small \& Medium Enterprise, vol. 2013, Article ID 330105, 20 pages

DOI: $10.5171 / 2013.330105$ 
predict but rather show the dynamics of the phenomenon under study.

We chose to analyse a Spanish manufacturer of professional skin care products (Case A), the authorized distributor of that manufacturer's products in Puerto Rico (Case B), and a skin-care service retailer who buys products from that manufacturer through the aforementioned distributor (Case $\mathrm{C}$ ).

\section{Industry Overview}

The Spanish aesthetics industry generates many products for both the professional and consumer markets ranging from packaging and beauty treatment appliances, to perfumes and hair and body cosmetics. Spain has consolidated its position as Europe's fifth largest producer of cosmetics and skin care products, accounting for an estimated $12 \%$ of total European turnover in the sector (Francés-Simón, A., 2010). Preliminary estimates for 2009 show a total sales volume of 4,500 million Euros for the Spanish aesthesis industry. In 2009, exports from this sector reached a value of $1,787.8$ million Euros. The main countries that receive Spanish cosmetics exports are France with 242.3 million Euros $(13.6 \%$ of the exported total), Germany, with 170.8 million Euros (9.6\%), Portugal with 162.1 million Euros (9.1\%), the United Kingdom with 158.9 million Euros (8.9\%), Italy with 115.2 million Euros (6.4\%), and the United States with 90 million Euros or 5\% (Cosmoprof Bologna 2010).

In Puerto Rico the professional aesthetics sector is registered under the Cosmetic and Beauty Products Industry, which includes a wide range of commercial and professional products such as perfumes, cosmetics, hair styling and skin care products. Professional aesthetics in Puerto Rico is included within the services and retail sector which is composed of approximately 400 retailers. Approximately 38 local and international professional aesthetics firms exist (San Juan Beauty Show, 2005; EuroImpact Trade Show, 2004). These firms have a presence in the country through small locally owned distributors (San Juan Beauty Show, 2009; EuroImpact, 2007, 2008, 2009). The United States (US) is the main supplier of the general Puerto Rican market, providing $86.3 \%$ of Puerto Rico's imports valued at $\$ 43$ million in 2004, followed by Colombia with imports valued at $\$ 2.6$ million, while Spain is the third largest supplier, providing aesthetics products valued at $\$ 996,867$ in this period. Between 2001 and 2004, aesthetics products increased from $28.7 \%$ to $64.9 \%$ of the value of Puerto Rico's total cosmetic and beauty products imports (ICEX, 2005).

Different from commercial beauty products, which are sold in pharmacies, supermarkets and wholesale stores (ICEX, 2010) professional aesthetics products are sold through distributors and authorized retailers. Professional aesthetics manufacturers are contained in a closed, regulated market dominated by SMEs. For the most part, professional aesthetic products are not attractive to large companies because the target market is comparably small with the exception of a few large organizations such as L'oreal with the Keraskin brand. Although some SMEs outsource certain services, these organizations are for the most part vertically integrated. Other firms rely on contract manufacturers for the production of their products (Newman \& Zhou, 2008). The antiaging skin care boom can account for the growing global skin care market which reached \$65 billion in 2007.

\section{Literature Review}

Given the limited resources and constant emergence of top-quality beauty products in the mass market, SMEs in the professional aesthetics industry are forced to maintain control and to be continuously innovative in order to remain competitive and to grow (Barson, 2010). SME innovation is generally manifested through product modifications, but is also apparent through process improvements, organizational structure, management, and marketing practices. 
Experts agree that innovation is the process by which entrepreneurs translate opportunities into marketable ideas and thus become catalysts for change (Kuratko, Donald, Hodgetts \& Richard, 2004). The innovation process is characterized by the interaction of market and non-market stakeholders and the outcome of their actions (Rothgang and Tretttin, 2005). BeiseZee and Rammer (2006) emphasize the importance of innovation as an interactive process between users and producers that allows the development of new products. Johannessen, Olsen and Lumpkin (2001), and Bhaskaran (2006) describe innovation as new activities, ideas, practices, or objects pertaining to individual units of operation. Innovation constitutes a systemic process in which a dynamic "feedback effect" occurs, demonstrated by a constant information exchange between participants (Kline \& Rosenberg, 1986). Innovation thus implies the development of external and internal networks and new ideas that emerge from these connections (Hansen \& Birkinshaw, 2007).

Business networks are vital to the innovation value chain because they can accomplish the objective of found solutions to a specific problem, and discover new ideas within a broad technology and product domain (Hansen \& Birkinshaw., 2007). Ting and Chiu (2007) found that both network competence and network location centrality have a significant positive impact on a firm's innovative performance. Rothgang and Trettin, (2005) argue that the integration of SMEs with stakeholders, through affiliation with a branch/trade group and collaboration with other firms, encourage innovations. These authors suggest that innovative success is tied to the combination of expertise and management knowledge that has been acquired through courses offered by craft organizations.

The network approach is relevant to the present study given that, in general, aesthetics manufacturers are geographically located in industrial clusters, facilitating the exchange of knowledge and ideas and the ability to be up-to-date with the latest industry trends. The clusters allow the creation of both formal and informal business networks, increasing the effectiveness of inter-firm knowledge exchange toward better innovative outcomes (Arikan, 2009). Shao, Chen and Chen (2008) suggest that a cluster innovation phenomenon arises from a collaborative innovation process of specialized SMEs in the same or related industries that cooperate with other stakeholders such as suppliers, customers, and other participants in the cluster.

To successfully generate innovations, a firm must work in the context of high levels of entrepreneurial orientation, market orientation, and technological capabilities within the organization. Verhees and Meulenberg (2004) state that the innovative orientation of the owner of a firm is a key variable of innovation in an SME. With their main objective being to explain the impact of innovation on the market performance of small firms, they propose a model in which a firm's innovativeness is linked to the value of the owner while domain-specific innovativeness is linked to the owner's interest in a specific domain.

Recent studies suggest that innovation, product improvement, and internationalization are associated with SME growth and performance (Beise-Zee \& Rammer, 2006; Wolff \& Prett, 2006). Based on their findings, Wolff \& Pett (2006) argue that product improvement mediates the impact of innovation on SME growth. However, these factors alone do not guarantee success. Both market orientation and entrepreneurial orientation reflect the strategic directions for the creation of innovations, superior performance, and international competitiveness (Ronyand, Drogue, \& Swinney, 2008; Armario, Ruiz, \& Armario, 2008; Renko, Carsrud, \& Brannback, 2009; Kara, Spillan \& DeShields, 2005; Keskin, 2006). Armario, Ruiz and Armario, (2008) indicate that by promoting a marketoriented culture, a firm can develop core 
capabilities such as market sensing, customer linking and channel bonding that promote competitiveness in foreign markets.

Market orientation facilitates the acquisition of market knowledge and a commitment of resources, thereby placing a firm in the position to identify and exploit new market opportunities. The acquisition of market knowledge increases innovation in the areas of both process and products. In the context of innovation, the value chain market is a major source of knowledge for innovation and firm performance (Kline \& Rossenberg, 1986; Hansen \& Birkinshaw, 2007; Roper, Du \& Love, 2008; Doran \& O'Leary, 2011). The importance of the market as a knowledge source, relies on "feedback effects" or input from various participants within the innovation value chain, aiding in the exploitation and transformation of these inputs into innovation outcomes (Doran \& O'Leary, 2011).

The strategic orientation choices of a firm are linked to the resources available to the firm. Maintaining a close relationship with both customers and markets while adopting a proactive, risky and innovative decisionmaking approach requires a firm to expend resources. In particular, highly committed human resources and the capability to implement the appropriate strategic activities and goals are necessary (Renko, Carsrud \& Brannback, 2009). Innovative processes and innovation capabilities are influenced by competent management and leadership within the firm. In addition to competency, a combination of company values, attitudes, working styles, and personnel culture are central to innovative capabilities (Pulkkanen, Risto, Lintuniemi, Matti, \& Harmaakorpi, 2005).

In the case of high tech SMEs, such as new biotechnology ventures, a competitive advantage arises from an innovative edge over competitors and in finding a niche where knowledge-based capabilities are at a premium (Renko, Carsrud \& Brannback, 2009). Although the professional aesthetics market is a narrow, closed market the above holds true to the limited resources and nature of this highly competitive market. Firms facing financial constraints need to comply with market regulations or satisfy uncertain demand of products or services such as SMEs, or firms perceiving risks from competitors, are more likely to innovate (Doran \& O'Leary, 2011).

\section{Methodology}

The present study is a qualitative case study (Yin, 1998) that aims to describe and elucidate the variables that affect innovation in the context of the professional aesthetics industry. To obtain reliable information, we included secondary data analyses of the firm's official reports, distributor's invoices, airway bills and bills of landing, price lists, emails, industry magazines, newspapers, trade shows catalogues (San Juan Beauty Show, 2005; San Juan Beauty Show, 2010), and industry and government official websites. These documents dated from 1997 to 2010. Official corporate reports and distributor invoices provided identification of products that were well positioned in the market and those which were not. Airway and lading bills, and price lists, provided information on new or reformulated products as well as products in the process of being phased out. Other secondary data aided in understanding market expectations and trends, and manufacturer positioning within the industry.

Primary data, including face-to-face detailed interviews was collected. This methodology allowed us to construct the ICM (Figure 1). The Model describes how an organization's orientations join with the organization's capabilities to produce innovation. In addition, the proposed ICM demonstrates the effects of innovation outcomes on the organization's goals. In the current study, the firm uses innovation as tool to reach its established goals. To achieve innovation outcomes, it is necessary for the firm to develop several capabilities (business 
networks, knowledge acquisition and strategic management).

We chose three firms representing three branches (manufacturer, distributor and retailer) of the industry's supply chain. The sample was selected after meeting the C.E.O. of Casmara de Puerto Rico, distributor of Casmara Cosmetics, S.A., during the San Juan Beauty Show, the largest fair in Puerto Rico where distributors of skin care products and professional of the beauty industry meet annually. The trade show was held on November 1-2, 2009 at the Puerto Rico Convention Center in San Juan, Puerto Rico.

We selected these SMEs because the distributor had previously agreed to participate in a research that we conducted this year about home based business owners in the aesthetics industry in Puerto Rico (Orengo-Serra \& Picon-Garcia, 2010). The distributor was able to serving as intermediary to contact directly the manufacturer and one recommended retailer. The final respondents, representing these companies, which agreed to participate in the study, were the International export manager of Casmara Cosmetics, S.A. (Case A), the C.E.O. of Casmara de Puerto Rico (Case B), and the owner/founder of Susan M. Olivera Spa (Case C).

We focused our study in the beauty industry because in the niche market of professional skin care, innovations in products and treatments for skin conditions, particularly, anti-aging and body rebuilding and refitting treatments have encouraged the proliferation of Spas and beauty clinics around the world, and also has gave a big boost to specialty contract manufacturers (Newman \& Zhou, 2010). According to Bernstein Research (2009), in 2007, global sales of beauty products reached $\$ 191$ billion, with skin care and hair representing $33 \%$ and $28 \%$ of the total global beauty expenditures, respectively (Bernstein Research, 2009).

\section{Innovative Conceptual Model}

The ICM was used to analyze the three case studies (A, B and C). As shown in Figure 1, the ICM demonstrates the relationship between an organization's orientations and the organization's capabilities to produce innovation. The proposed ICM demonstrates the effects of innovation outcomes on the organization's goals. Based on existing literature on SME innovation, the orientations most related to innovation are MO (market orientation), LO (learning orientation), EO (entrepreneurial orientation), and TO (technological orientation). We focus on these orientations because aside from the TO, have been the most extensively documented. However, the relationships of these orientations toward innovation have not been treated on niche markets; where due to its specific characteristics SME's rely more on its orientations. For the most part MO and EO can simultaneously contribute to innovation (Renko, Carsrud \& Brannback, 2009). MO is the focus on knowledge that provides a source of ideas for change and improvement through market information processing and marketing strategies (Keskin, 2006; Verhees \& Meulenberg., 2004). LO is the ability of the firm to change practices and beliefs in order to innovate (Keskin, 2006). EO is the extent to which a firm is willing to accept risk and be competitively aggressive (Lumpkin \& Dess, 1996). T0 is a firm's commitment to develop its technology base through direct investments in research and development (R\&D) and/or strategic technology alliances with other firms (Renko, Carsrud \& Brannback, 2009). Unlike the concept of technological capability which refers to the technology as an asset, T0 covers the commitment of the company toward acquiring and exploiting these technological capabilities. In the proposed ICM the orientations are measured by constructs which have been statistically assessed for reliability (Keskin, 2006; Renko, Carsrud \& Brannback, 2009; Naver \& Slater, 1990). MO was measured by collecting and using information, strategy development, and strategy implementation. LO was measured 
by the commitment to learning, shared vision, open mindedness and intraorganizational knowledge sharing. EO was assessed by autonomy, proactiveness, competitive aggressiveness, and risks. Lastly, TO was evaluated by technology collaboration, knowledge collaboration, and commitment to $R \& D$.

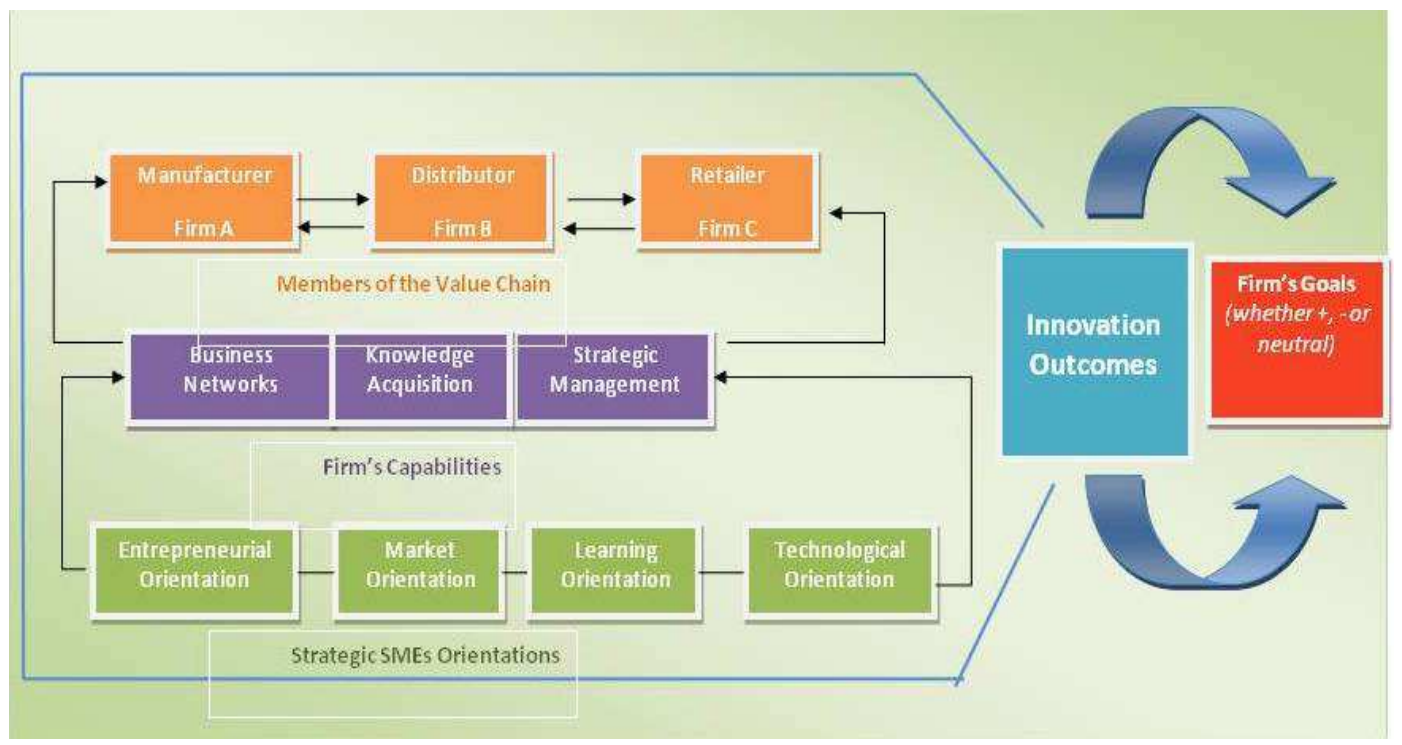

Figure 1: Innovative Conceptual Model in the Innovation Value Chain

The model identifies the effects of specific constructs on each capability of the organization. There is a consensus that capabilities that contribute to innovation can be grouped into three categories: business networks (BN), knowledge acquisition (KA), and strategic management (SM). $B N$ is the relationship between a firm's management team and employees with customers, suppliers, competitors, government, distributors, bankers, families, friends, and any other stakeholders that promote innovative competitiveness and differentiated goods and services, and internationalization (Zain, Mohamed \& Siew, 2006; and Gulati, 1999). $K A$ is the process by which firms gradually exchange tacit and technical knowledge to generate innovative outcomes, business export performance and competitiveness (Arikan, 2009; Andersson \& Johnasson, 2008; Tolstoy, 2009). SM is a set of managerial decisions and actions allowing an organization to operate successfully in a dynamic, innovative and complex environment (Wheleen \& Hunger, 2008; and
Kotler, \& Lane, 2006).The proposed ICM reveals how business capabilities result in innovations and the effect of these innovations on firm goals.

\section{Description of Innovation by Each Case Study}

\section{Case A: Manufacturer}

The manufacturer in the first case study was established in Spain in 1974 and is located in the city of Valencia, at the Bobalar industrial cluster. The company is an international SME manufacturer of high quality professional aesthetics products. The manufacturer has an in-house research, development, and innovation (R\&D\&I) department. The company has a presence in over 50 countries worldwide, employs an estimated 50 people, and accounts for more than 60,000 Euros per month in the labour force. The company's blockbuster product is a well-known Algae Peel Off mask, and several treatment lines for different skin conditions. Each line also 
produces retail products for homecare. Exclusive distributors provide products to beauty salons, spas, health clinics, and dermatologists. Internet is extensively used by the manufacturer as a strategy for expanding distribution worldwide. The medium-high and high income classes provide a target market for the company.

\section{Case B: Distributor}

The distributor is a 5-employee microbusiness, allowing total management control. The organizational structure is flat, and corporate policies are informal. The company was established in 1994 and in 2001, it was restructured to supply exclusively Case A manufacturing products, and to offer services of continued education, and training. The micro-firm supplies the entire Puerto Rican aesthetics market through authorized retailers. The distributor represents a link between the norms and values of the manufacturer and each specific market.

\section{Case C: Retailer}

The owner of the retailing business is also the manager. She has a BBA in microbiology and a Master's Degree in Medical Technology. She is 34 years old with 9 years of industry experience. These characteristics are important in that they are not the usual features of traditional retailers in this industry. More commonly, retailers are aestheticians who have pursued a technical career in aesthetics or cosmetology. The business was established at the owner's home in 2001 to focus on middle to high class women, homosexual, and married heterosexual men over 30 years old. The owner has equipment that is more sophisticated than is needed to be competitive in the industry. Her business occupies a $120 \mathrm{sq} \mathrm{ft}$ room containing one spa facial bed (cabin), an Eight in One Analogue Multifunction Machine, towel and depilatory warmers, business storage, and other equipment. The business is run by the owner exclusively and serves 4 or 5 customers per day, resulting in less than 40 servicing hours per week. The owner is also in charge of her own marketing. Due to market demand, she offers a wide range of treatments. The clientele consists of professional, knowledgeable, and up-to-date clients who know exactly what they want. The retail business is located in an urban zone in the western part of Puerto Rico, in the municipality of Mayaguez, where approximately 17 aesthetics businesses are open for an estimated population of 98,434 (http://209.68.12.238/censo2000/municipi os.php?municipio=MY).

\section{Case Analyses}

The following analysis attempts to demonstrate the interactive nature of the proposed ICM model. Tables 1, 2, and 3 are included to help in a comprehensive understanding of the analysis and the findings. The model reveals the relationship between orientations (MO, LO, EO and TO) and business capabilities (BN, KA and SM).

The scientific nature of the aesthetics industry and rapidly changing needs force the manufacturer to commit large share investments to R\&D. Firms within the regulated aesthetics segment of the beauty industry report excessive perceived risk in the access of funds to overcome financial pressure. The encouragement of collaborative networks and interactions with other members of the value chain increase the probability of innovation (Doran et al, 2011).

\section{Manufacturer and Distributor Relationship}

Interestingly, we found that manufacturer managers are not generally risk seekers. However, the aggressive nature necessary for survival in the industry forces them to take risks. The manufacturer is located in a cluster with direct competitors, providing a challenging and educational environment. Price wars are avoided due to the large investment necessary to provide a high end, effective product. Competition, therefore, is 
based on quality. The manufacturer is forced to focus on adding value, to ensure quality, avoid costly production redundancies, and meet or exceed distributor's expectations. In terms of strategic management, trust between manufacturer and distributor is vital for the organization's operations as well as part of the organizational culture. The manufacturer carefully chooses its distributors and creates close relationships through face to face exchanges, formal and informal meetings, and collaboration on projects and marketing plans (e.g. sharing of expenses on trade shows and other promotions). For the manufacturer, "effectively positioning their provided outcomes -e.g. quality products and improvements, discounts, support services-, can gain a competitive advantage in the marketplace through more cooperative, satisfied, and productive distributors" (Anderson \& Narus, 1984). The company products are directly tied to scientific advances, often requiring alterations in key processes such as manufacturing and marketing. Therefore, products are continually turning over and services are continually redefined. A constant accumulation of information is vital to keep up with new scientific advances, and to stimulate innovative ideas. Building managerial capabilities for continuous innovation within the firm is needed (Björk, Boccardelli \& Magnusson, 2010). Failing to do so, threatens the company survival.

The distributor serves as a bridge between the manufacturer and the retailer and thus must focus on innovation benefits of products and offer training on use of new products. Although aggressiveness is key to survival in the industry, a rush to innovate, dropping products before reaching maturity, can create "particular innovation problems" (Hansen \& Birkinshaw, 2007), causing more harm than good. The distributor, therefore, must choose which of the existing products to buy from the manufacturer, and large sectors of market needs may be left unattended. These issues represents distributor risks, which left unresolved may result in loss of profits, market share and customer satisfaction. If products are no longer desired in local markets, the cooperative relationship between manufacturer and distributor will become increasingly weak, even to the point of termination, if there is no innovation outcome or if product innovation does not keep pace with distributors market expectations (Wang \& Kess, 2006). To minimize these possible adverse effects, the distributor strategic management relies on strengthening and taking full advantage of business networks. Business networks allow information sharing, leading to enhancement of learning orientation. The distributor becomes indispensable in identifying the stage of the product marketing cycle in the local market. As a product reaches maturity in a large number of markets, it is often substituted by a novel product (Kotler \& Lane, 2006) and thus, strategic management on the part of the manufacturer is based on replacing mature products with more innovative ones.

As observed in Figure 2, most products in the aesthetics industry have a very short life cycle because the market demands novelty. Products in the declining phase are quickly substituted by new products that contain innovative ingredients to treat similar conditions. However, if science does not provide a novel ingredient, then the product is kept in the market as long as there is demand for it. Global competition forces Case $A$ to be updated with the newest technologies. In fact, $3.4 \%$ of total company investment goes to R-D\&I. 


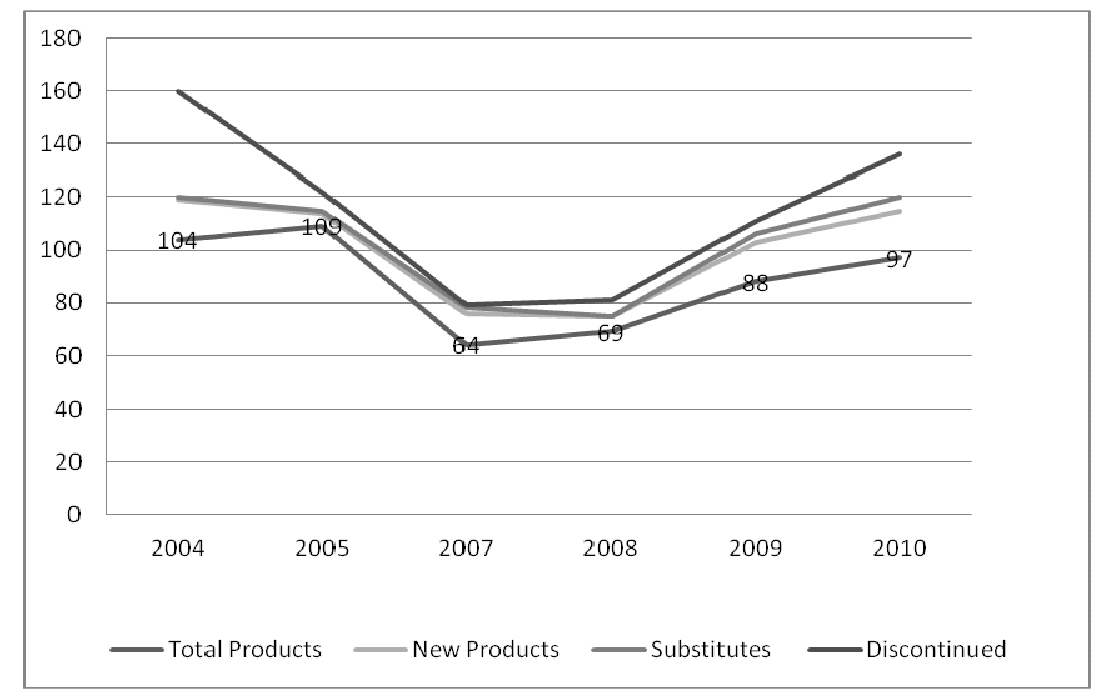

Note: Substitutes Products are those products still in the market, which had been reformulated by the addition of new active ingredients. The figure does not show any data of 2006 given the inconvenient to access information for this year. In 1996 the manufacturer had in the worldwide market, 23 professional lines of products or 116 products. In 2010 , the manufacturer registered only 12 professional dermocosmetic lines, or 97 products, reducing its brand portfolio to $68.7 \%$ (of 141 products available in 1996 to 97 in 2010).

\section{Figure 2: Product Innovations of Case A}

However, the strategic management of the distributor and the retailer is based mainly on proactiveness. The distributor must be effective in predicting what the future market will want, in order to avoid overstocks which are costly and often cannot be stored indefinitely. Business networks allow the manufacturer to collect crucial information on each market. Failing to do so would result in loss of market share to the manufacturer and retailer, and would compromise survival of the distributor.
The distributor must purchase a license for distribution and is therefore at high risk and must accurately predict the market. Distributor productivity increases the ability for the manufacturer to act proactively and therefore aggressively. This dependence of the manufacturer on the distributor strengthens the business network and in turn, the knowledge acquisition required for innovation and the strategic management to be on target. Furthermore, the business network enhances decision-making efficiency, translating into market share growth and profit gains. 
able 1: Effect of Strategic Orientations and Innovation Outcomes on Manufacturer Goals

\begin{tabular}{|c|c|c|c|c|c|c|c|c|c|}
\hline \multicolumn{10}{|c|}{ ORIENTATIONS } \\
\hline CAPABILITIES & INNOVATIVE & \multicolumn{2}{|c|}{ MO } & \multicolumn{2}{|c|}{ LO } & \multicolumn{2}{|c|}{ EO } & \multicolumn{2}{|c|}{ TO } \\
\hline & & Goal & Effect & Goal & Effect & Goal & Effect & Goal & Effect \\
\hline $\begin{array}{l}\text { Business networks } \\
\text { - Development of } \\
\text { business ties with } \\
\text { commercial associations, } \\
\text { industry, and public } \\
\text { institutions } \\
\text { - In-depth selecting } \\
\text { process of distributors } \\
\text { from each identified } \\
\text { market }\end{array}$ & $\begin{array}{l}\text { Identify market } \\
\text { needs and } \\
\text { expectations } \\
\text { Keep up with } \\
\text { tendencies } \\
\text { Produce new } \\
\text { formulations and } \\
\text { products }\end{array}$ & $\begin{array}{l}\text { Increase } \\
\text { profits } \\
\text { (YES) }\end{array}$ & 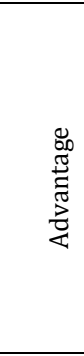 & $\begin{array}{l}\text { Customer } \\
\text { satisfaction } \\
\text { (YES) }\end{array}$ & 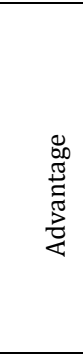 & $\begin{array}{l}\text { Increase } \\
\text { market } \\
\text { share } \\
\text { (YES) }\end{array}$ & 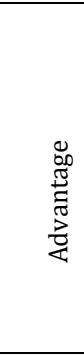 & $\begin{array}{l}\text { Market } \\
\text { expansion } \\
\text { (YES) }\end{array}$ & 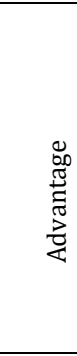 \\
\hline $\begin{array}{l}\text { Knowledge acquisition } \\
\text { - In-house R\& D } \\
\text { - Knowledgeable HR } \\
\text { (high skill workforce) } \\
\text { represents competitive } \\
\text { salaries for employees }\end{array}$ & $\begin{array}{l}\text { New products } \\
\text { development } \\
\text { Constant } \\
\text { improvement } \\
\text { through product } \\
\text { differentiation }\end{array}$ & $\begin{array}{l}\text { Increase } \\
\text { profits } \\
\text { (no } \\
\text { effects) }\end{array}$ & 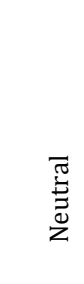 & $\begin{array}{l}\text { Customer } \\
\text { satisfaction( } \\
\text { YES) }\end{array}$ & $\begin{array}{l}0 \\
\stackrel{\infty}{\pi} \\
\stackrel{0}{0} \\
\frac{\pi}{4}\end{array}$ & $\begin{array}{l}\text { Increase } \\
\text { market } \\
\text { share } \\
\text { (YES) }\end{array}$ & 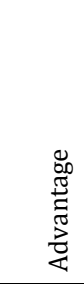 & $\begin{array}{l}\text { Market } \\
\text { expansion } \\
\text { (YES) }\end{array}$ & 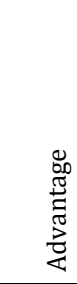 \\
\hline $\begin{array}{l}\text { Strategic management } \\
\text { - } \quad \text { Bureaucratic and } \\
\text { vertical organization } \\
\text { structure } \\
\text { - Short-term strategic } \\
\text { planning } \\
\text { - High price products } \\
\text { focused on medium-high } \\
\text { segment } \\
\text { - Short product life- } \\
\text { cycle } \\
\text { - Cluster location } \\
-\quad \text { High quality products }\end{array}$ & $\begin{array}{l}\begin{array}{l}\text { Constants product } \\
\text { improvements }\end{array} \\
\text { Reformulated } \\
\text { products } \\
\text { Products in the } \\
\text { decline curve of the } \\
\text { life-cycle are taken } \\
\text { out of market }\end{array}$ & $\begin{array}{l}\text { Increase } \\
\text { profits } \\
\text { (neutral) }\end{array}$ & 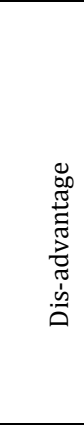 & $\begin{array}{l}\text { Customer } \\
\text { satisfaction } \\
\text { (neutral) }\end{array}$ & 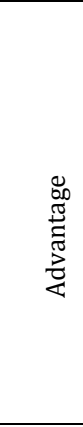 & $\begin{array}{l}\text { Increase } \\
\text { market } \\
\text { share } \\
\text { (neutral) }\end{array}$ & 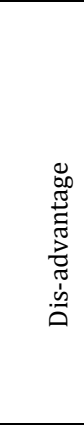 & $\begin{array}{l}\text { Market } \\
\text { expansion } \\
\text { (YES) }\end{array}$ & 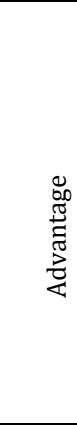 \\
\hline
\end{tabular}

Due to resource limitations and a fairly rigid hierarchical organizational culture, the manufacturer traditionally maintains a distant relationship with distributors and does not maintain any relationship with retailers. Conversely, the distributor has a flat structured organization where information runs freely while the retailer has no employees whatsoever. The manufacturer's bureaucratic structure weakens its market orientation for innovation, in the context of customization strategy. To overcome this innovation problem, companies develop strong relationships to facilitate knowledge acquisition, reducing the number of steps toward the generation of new ideas (Hansen
\& Birkinshaw, 2007). The manufacturer relies on the distributor for both formal and informal business networks which provide intelligence and dissemination outside the organization.

\section{Relationship between the Distributor and Retailer}

The professional aesthetics industry provides retailers with a wide variety of machinery for use with products. Due to scientific training, the retailer in Case $C$ is drawn to the newest and most sophisticated machinery. The technological knowledge and modern aesthetics equipments provide the retailer with the competency to offer a large variety 
of highly effective treatments to clients (Barson, 2010). Furthermore, the technological savvy of the retailer provides an additional outlet to bring innovative ideas to the manufacturer. The retailer's commitment to learning and the strong business networks created by the distributor set the ground for innovative products to flourish.

Existing and upcoming machinery can enhance product performance and thus increase market share. The manufacturer acquires knowledge of machinery innovation through business networks (e.g. customers, market trends, and companies), seminars, conferences and trade shows. The technological knowledge acquired from this niche market can help the manufacturer to become proactive in larger, technologically lagging markets. The niche market is then not only financially profitable but also a knowledge powerhouse for the manufacturer. A strong relationship between the distributor and retailer (as was observed in the current case studies) can facilitate development and implementation of a strategy, ultimately enhancing the market orientation strategy and to adopt technological orientation to be more competitive in their domestic market. The strategic management is thus shared. Firms within this market are too small to acquire expensive technological resources, such as an R\&D department, and therefore, they must build and maintain strong business networks to set a coherent management strategy which will allow knowledge acquisition and ultimately enhance all market orientation constructs, making the local market more competitive. 
Table 2: Effect of Strategic Orientations and Innovation Outcomes on Distributor Goals

\begin{tabular}{|c|c|c|c|c|c|c|c|c|c|}
\hline \multicolumn{10}{|c|}{ ORIENTATIONS } \\
\hline CAPABILITIES & INNOVATIVE & \multicolumn{2}{|c|}{ MO } & \multicolumn{2}{|l|}{ LO } & \multicolumn{2}{|c|}{ EO } & \multicolumn{2}{|c|}{ TO } \\
\hline & & Goal & Effect & Goal & Effect & Goal & Effect & Goal & Effect \\
\hline $\begin{array}{l}\text { Business networks } \\
\text { - Strength manufacturer } \\
\text { ties with final consumer } \\
\text { market through } \\
\text { information exchanges }\end{array}$ & $\begin{array}{l}\text { Make innovation } \\
\text { accessible to local } \\
\text { market }\end{array}$ & $\begin{array}{l}\text { Increase } \\
\text { profits } \\
\text { (YES) }\end{array}$ & 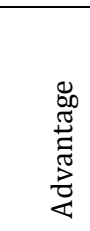 & $\begin{array}{l}\text { Customer } \\
\text { satisfaction } \\
\text { (YES) }\end{array}$ & 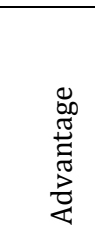 & $\begin{array}{l}\text { Local } \\
\text { market } \\
\text { expansion } \\
\text { (YES) }\end{array}$ & 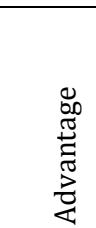 & $\begin{array}{l}\text { Customer } \\
\text { retention } \\
\text { (no effect) }\end{array}$ & $\begin{array}{l}\text { त्ञ } \\
\stackrel{0}{0} \\
z\end{array}$ \\
\hline $\begin{array}{l}\text { Knowledge acquisition } \\
\text { - Increase market } \\
\text { intelligence strategy }\end{array}$ & $\begin{array}{l}\text { Generate innovation } \\
\text { that fits market } \\
\text { expectations } \\
\text { Capabilities to } \\
\text { choose accurate } \\
\text { existing innovation } \\
\text { that fits specific } \\
\text { market needs }\end{array}$ & $\begin{array}{l}\text { Increase } \\
\text { profits } \\
\text { (no } \\
\text { effects) }\end{array}$ & $\begin{array}{l}\bar{\pi} \\
\stackrel{5}{\Xi} \\
z\end{array}$ & $\begin{array}{l}\text { Customer } \\
\text { satisfaction } \\
\text { (YES) }\end{array}$ & 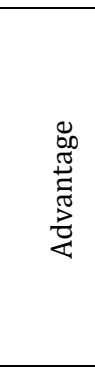 & $\begin{array}{l}\text { Local } \\
\text { market } \\
\text { expansion } \\
\text { (YES) }\end{array}$ & 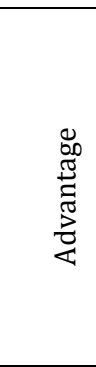 & $\begin{array}{l}\text { Customer } \\
\text { retention } \\
\text { (YES) }\end{array}$ & $\begin{array}{l}0 \\
\stackrel{\infty}{\pi} \\
\stackrel{\pi}{\pi} \\
\frac{\pi}{2} \\
\frac{0}{2}\end{array}$ \\
\hline $\begin{array}{l}\text { Strategic management } \\
\text { - } \quad \text { Flat management style } \\
\text { - Joint activities with } \\
\text { retailers and } \\
\text { manufacturer } \\
\text { - Control } \\
\text { manufacturer's image } \\
\text { - Keep retailers loyalty } \\
\text { to manufacturer } \\
\text { - Coach retailers in new } \\
\text { products }\end{array}$ & $\begin{array}{l}\text { Make innovation be } \\
\text { accepted by local } \\
\text { market }\end{array}$ & $\begin{array}{l}\text { Increase } \\
\text { profits } \\
\text { (YES) }\end{array}$ & 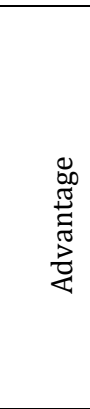 & $\begin{array}{l}\text { Customer } \\
\text { satisfaction } \\
\text { (YES) }\end{array}$ & 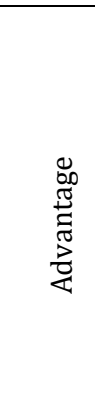 & $\begin{array}{l}\text { Local } \\
\text { market } \\
\text { expansion } \\
\text { (YES) }\end{array}$ & 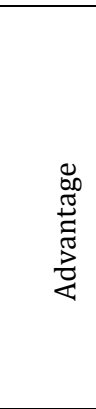 & $\begin{array}{l}\text { Customer } \\
\text { retention } \\
\text { (YES) }\end{array}$ & 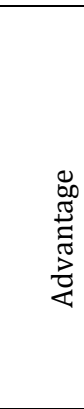 \\
\hline
\end{tabular}


Managing innovations require overcoming disagreements that help to create an appropriate climate where people can share and build upon each other's ideas and suggestions (Isaksen \& Ekvall, 2010). The distributor and retailer developed a close personal relationship to manage disagreements related to new ideas of forms of innovations, and facilitating knowledge acquisition sharing. In some cases, as was observed in the present study, the distributor proactiveness enables the manufacturer to be more flexible in gathering reliable and accurate market information. These results suggest that constructs of EO proactiveness can open new avenues between manufacturer and retailer, helping the manufacturer in strategy implementation, which enhances the manufacturer market orientation. This observation is exemplified by the manufacturer R\&D establishing a direct relationship with the retailer and thus demonstrating flexibility. Although not formally established, it is implicitly acknowledged that one of the distributor's roles is to bring retailer concerns to the manufacturer.

\section{Relationship between Manufacturer and Retailer}

The retailer is owned and operated by one individual and therefore, autonomy toward internal decisions is obvious. The retailer is unique in that she has above average scientific knowledge permitting her to go beyond firm boundaries in creating product innovation leading to competitiveness within the field. The distributor is a key component in a retailer's loyalty to the manufacturer. Innovations are often reflected in a price increase because, in general, these innovations are the addition of new active ingredients to products. The distributor, therefore, must demonstrate that the benefits achieved by the innovation out weight the product's price increase.

Although the manufacturer is a hierarchical firm, the R\&D manager is provided with enough autonomy to informally choose which outsiders can participate in the product innovation process. The R\&D department has direct contact with the retailer and this nontraditional relationship has led to a more targeted innovative product, satisfying market desire. Without this unique relationship, such targeted innovation may have taken many years of trial and error, wasting time and resources. In the current study, exchanges between the retailer and the manufacturer R\&D department (promoted by the distributor) have resulted in the launching of two innovative products worldwide during 2005 and 2010: Re6tense based on Silcare 180M20®, and Body-Art Sculpting Solution based on neo-actives Timeline $\AA$, and Biosculptine ${ }^{\circ}$ (Dr. Víctor A. Orengo Serra, Foundation, Inc, 2005; 2010). There was never a formal contract between the manufacturer and retailer during the process of generating these two innovations.

Similarly, the former distributor of Case A (a physician) proposed an active ingredient to treat heavy legs and cellulite. This suggestion resulted in the worldwide launching of PR75 treatment (Eurocontrol, 1996). Informal relationships, therefore, aid in the generation, selection, and nurturing of the most promising ideas, ultimately leading to a strengthening of the innovation value chain (Hansen \& Birkinshaw, 2007). 
Table 3: Effect of Strategic Orientations and Innovation Outcomes on Retailer Goals

\begin{tabular}{|c|c|c|c|c|c|c|c|c|c|}
\hline \multicolumn{10}{|c|}{ ORIENTATIONS } \\
\hline CAPABILITIES & INNOVATIVE & \multicolumn{2}{|c|}{ MO } & \multicolumn{2}{|c|}{ LO } & \multicolumn{2}{|c|}{ EO } & \multicolumn{2}{|c|}{ T0 } \\
\hline & & Goal & Effect & Goal & Effect & Goal & Effect & Goal & Effect \\
\hline $\begin{array}{l}\text { Business networks } \\
\text { - Customer assessment } \\
\text { - Information } \\
\text { exchanges with } \\
\text { manufacturer } \\
\text { - Technology access }\end{array}$ & $\begin{array}{l}\text { Accomplishment of } \\
\text { customer's high } \\
\text { tech and quality } \\
\text { expectations }\end{array}$ & $\begin{array}{l}\text { Increase } \\
\text { profits } \\
\text { (YES) }\end{array}$ & 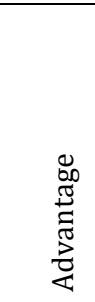 & $\begin{array}{l}\text { Customer } \\
\text { satisfactio } \\
n \text { (YES) }\end{array}$ & 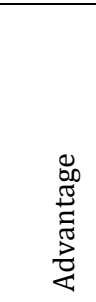 & $\begin{array}{l}\text { Customer } \\
\text { retention } \\
\text { (YES) }\end{array}$ & 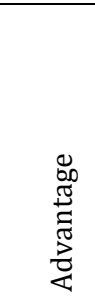 & $\begin{array}{l}\text { Customer } \\
\text { acquisition } \\
\text { (YES) }\end{array}$ & 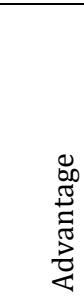 \\
\hline $\begin{array}{l}\text { Knowledge acquisition } \\
\text { - } \quad \text { Continued education } \\
\text { - Sciences background } \\
\text { and expertise }\end{array}$ & $\begin{array}{l}\text { More targeted } \\
\text { products } \\
\text { Better } \\
\text { communication } \\
\text { flow with R\& D } \\
\text { department } \\
\text { Access to } \\
\text { innovative } \\
\text { products }\end{array}$ & $\begin{array}{l}\text { Increase } \\
\text { profits } \\
\text { (no } \\
\text { effects) }\end{array}$ & 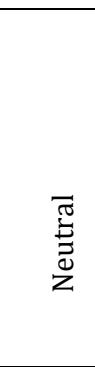 & $\begin{array}{l}\text { Customer } \\
\text { satisfactio } \\
\text { n(YES) }\end{array}$ & 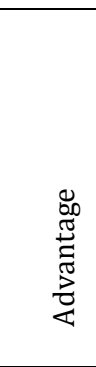 & $\begin{array}{l}\text { Customer } \\
\text { retention } \\
\text { (YES) }\end{array}$ & 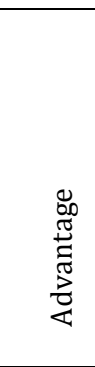 & $\begin{array}{l}\text { Customer } \\
\text { acquisition } \\
\text { (YES) }\end{array}$ & 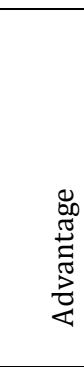 \\
\hline $\begin{array}{l}\text { Strategic management } \\
\text { - Decision making } \\
\text { process relies in one } \\
\text { person } \\
\text { - Short-term strategic } \\
\text { planning }\end{array}$ & $\begin{array}{l}\text { Fast response to } \\
\text { market changes }\end{array}$ & $\begin{array}{l}\text { Increase } \\
\text { profits } \\
\text { (YES) }\end{array}$ & 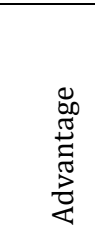 & $\begin{array}{l}\text { Customer } \\
\text { satisfactio } \\
\mathrm{n}(\mathrm{YES})\end{array}$ & 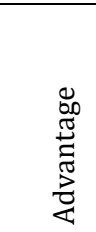 & $\begin{array}{l}\text { Customer } \\
\text { retention } \\
\text { (YES) }\end{array}$ & 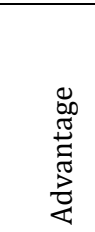 & $\begin{array}{l}\text { Customer } \\
\text { acquisition } \\
\text { (YES) }\end{array}$ & 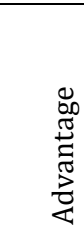 \\
\hline
\end{tabular}


These results demonstrate that the entrepreneurial orientation construct of autonomy enhances knowledge acquisition. A more efficient knowledge acquisition mechanism in turn, results in efficient use of time and resources which ultimately translates into lowering costs, augmenting profits and gaining market share for the manufacturer and retailer.

The close relationship of the $R \& D$ department strengthens the continued scientific education of the retailer and hones the retailer's tacit knowledge about what to observe in the market for identification of possible targeted innovations. Knowledge acquisition derived from both continued education and first hand observation increases effective strategic management allowing more rapid and accurate decision making and ultimately increases both manufacturer and retailer profits. The new product results in customer satisfaction leading to customer retention and new clients.

Lumpkin and Dess (1996) suggested that risk taking is critical to manufacturer entrepreneurial orientation. To offset risk, firms rely on traditional knowledge acquisition through means such as formal market research studies. However, these studies are too costly form SMEs. Furthermore, the markets they reach are too diverse and volatile for a standard market study to be of use. Therefore the manufacturer of SMEs must rely on business networks to learn about the market. The entry strategy into these markets is through a licensed distributor. Risk is then transferred from the manufacturer to the distributor who must invest a large sum of money to buy a license. The transfer of risk lowers the manufacturer costs associated with uncertainty. As is observed in the case of the distributer under study, in many industries local markets are composed by loyal consumers that are hesitant to switch to other brands of new lines within the manufacturer portfolio (Hansen \&
Birkinshaw, 2007). This situation increases distributor risk because products are not individually customized to satisfy each market preference.

\section{Findings}

\section{Interacting in the Value Chain}

Because the manufacturer, distributer and retailer interact in a niche market, survival is dependent on a focus on company strengths. The management strategy of the manufacturer relies on the distributor to identify where within each local market the brand is strongest. Some brands are more popular for their facial products while others are more popular for their body products. Experienced retailers often specialize in several types of treatments. Specialization is the differentiation strategy of the retailer to remain competitive while quality assurance became a key to achieve customer satisfaction. To maintain quality, retailers are required to buy high quality, expensive products. Consequently, high prices are often necessary to increase profits. Due to market volatility, the management strategy of the three firms focuses on market position and reputation. The manufacturer produces standard products and the distributor must gain market acceptance for the product.

The manufacturer is removed from customers, and therefore the manufacturer managerial strategy does not directly consider customer desires in pricing or products. The distributor has the option to buy the products the retailer desires and therefore the manufacturer has to adapt in order to be competitive. Since the distributor and retailer are closer to the market than the manufacturer, they are more concerned with customer needs. Because of the informality of the retailer/distributor relationship, knowledge acquisition and business networks expansion are planned and implemented quickly. This dynamic allows the distributor to more easily convince the manufacturer to act quickly before the market has shifted. 
Innovation and timely market knowledge are key factors for firm survival. Therefore, knowledge acquisition must be a core value and an investment. Radical innovation of products is expensive and risky. The current case studies demonstrated that the three firms are continually honing their strategic management and business networks to better acquire knowledge. The studied firms are persistently searching for the newest information to keep up with industry tendencies to enhance market orientation. However, each firm establishes market orientation in a different manner. Manufacturer R\&D employees are required to take continuing education courses. As part of its license contract, the distributor acquires knowledge about new products to teach retailers how to use them. Improper use of products by retailers can result in market share loss for the manufacturer and ethical issues. Incorrect use of some professional aesthetics products can lead to serious health problems causing a loss in reputation and possibly legal action. Therefore commitment to learning is more than a competitive advantage; survival is dependent on it.

It is imperative to maintain a common purpose throughout a supply chain. The three firms in the current case studies are SMEs and therefore, a common purpose is easy to disseminate internally. However, the same is not necessarily true in a large supply chain, especially for the manufacturer. Each firm in a large supply chain easily enhances its own learning orientation internally but not when implementing strategies for enhancement of business networks. While the three firms studied here have a common purpose, there are often clashes about how to best attain these purposes. Both the manufacturer and retailer want to increase income and expand market share by maintaining and acquiring clients. Nevertheless, the distributor's interests lie solely in the local market while the manufacturer is interested in the most profitable markets. The manufacturer would be willing to sacrifice a specific local market to benefit a larger, more profitable one. This example demonstrates an inconsistency in the shared vision between the manufacturer and distributor. This discrepancy can harm distributor goals to the extent of extinction, and shrink the market share of the manufacturer. The distributor must maintain a competitive market. This presents a challenge to small markets such as Case B. Through years of a close relationship between the manufacturer and distributor a trust has developed and the distributor has learned the manufacturer organizational culture. This arrangement facilitates the development of a strategic management which coincides with the manufacturer. Values on quality, improvement and importance of scientific knowledge are passed down through business networks from manufacturer to retailer while values on proactiveness, market knowledge and product performance are passed from retailer to manufacturer. This bidirectional relationship has resulted in a more openminded attitude of the manufacturer toward the distributor. Furthermore the relationship enhances a shared vision which cements the business networks and leads to a more coherent and coordinated strategic management style producing more accurate and reliable knowledge acquisition. Additionally, the learning orientation of both organizations is improved. A learning orientation under a weak strategic management can result in a waste of resources.

The aesthetics market is particularly volatile and therefore, continual updates are critical. This is especially important when available knowledge acquisition resources are limited. Firms must learn from their mistakes and adjust quickly. The three studied firms share a commitment to learning and intra organizational knowledge sharing. These two constructs of the learning orientation do not on their own lead any of the firms to achieve their goals. However, a commitment to learning enhances the market orientation constructs of information use and dissemination while the intra organizational 
sharing strengthens business networks. These two constructs of the learning orientation enhance the entrepreneurial and market orientation effects on the three firms' goals. Conclusions, Implications, and Future
Research Directions

Most previous studies on firm innovation and performance based on strategic orientations (MO, EO, LO, and TO) have been empirical studies that were applied to firms from heterogeneous industries. The present study is the first to apply these strategic orientations to the three branches of the industry value chain of a single, regulated industry, oriented to a niche market. The main contribution of the current study is the analysis of innovation through the application of theoretical approaches of entrepreneurial strategic orientations to the three branches of an industry using the ICM. The proposed ICM demonstrates the organization's orientation ties with each business capability, the effect of these ties on innovation, and, ultimately, how the achieved innovations affect the organization's goals.

The innovative conceptual model (ICM) in the aesthetic industry has implications for the accessibility of knowledge provided by the Internet. The easy access to knowledge allows the consumer to readily receive information, forcing other members of the chain to constantly seek innovative solutions to optimize consumer expectations. As depicted in the data, value chain network management implies networked solutions throughout the value chain. Without the participation of the distributor and the retailer in innovation, access to valuable information and the success of innovation outcomes would not be guaranteed. However, this does not mean that the orientations (MO, EO, LO, TO) and capabilities (BN, KA, SM) guarantee positive innovation outcomes. In fact, the findings from the current study reveal that goals and expected outcomes are not always achieved.
Other specific managerial and marketing implications are also suggested.

The ICM allows the retailer to play an intermediary role in the process of transferring knowledge on market trends and new skin problems. The retailer contributes positively to the consumer's selfesteem, which is tied to emotional health and physical appearance. The manufacturer's motto: "First Efficacy \& Then Beauty" supports this implication. The retailer guarantees a safe investment in a product that is not necessarily inexpensive but of high quality.

For the distributor, the ICM represents active integration into the innovation process, providing solutions to consumer demands and therefore constantly optimizing stakeholder expectations. In addition, it is beneficial to maintain a high value product portfolio that can mitigate competition, and counterfeiting by manufacturers from countries where trade policies lack ethical considerations.

The ICM helps the manufacturer to maintain a leadership role worldwide and differentiate its self from the commercial sector. Additionally, the ICM facilitates, streamlines, and democratizes the process of knowledge acquisition, which, when integrated into the value chain, is less risky because the innovation process is executed from a rational standpoint based on first hand market information.

The present study contributes to a better understanding of the innovation value chain, particularly in a regulated sector. As demonstrated through our case studies, niche markets, require the development of strong relationships between the partners of the value chain, not only for survival but to be competitive. It does require the firms to develop business capabilities that are linked to some strategic orientations that explain this dynamic. 
Our results support the literature on innovation value chains and shed light on the importance of business capabilities of each participant within the chain, particularly of SMEs. The current results suggest that future research should pursue in-depth studies to investigate whether the dynamic context of the ICM behaves similarly between SMEs and multinationals firms (MNFs). The present results are based on the case study method and therefore, only theoretical generalizations can be applied. It is necessary to replicate this study using quantitative techniques to determine whether the findings hold true for SMEs drawn from other industries.

\section{References}

Anderson, C. R. \& Zeithamil, C. P. (1984). "Stage of the Product Life Cycle, Business Strategy, and Business Performance," Academy of Management Journal 27 (1), 5-24.

Anderson, J. C. \& Narus, J. A. (1984). "A Model of the Distributor's Perspective of Distributor-Manufacturer Working Relationships," Journal of Marketing 48, 6274.

Andersson, M. \& Johansson, B. (2008). "Innovation Ideas and Regional Characteristics: Product Innovations and Export Entrepreneurship by Firms in Swedish Region," Growth and Change 39 (2), 193-224.

Arikan, A. T. (2009). "Interfirm Knowledge Exchanges and the Knowledge Creation Capability of Clusters," Academy of Management Review 34 (4), 658-676.

Armario, J. M., Ruiz, D. M. \& Armario, E. M. (2008). "Market Orientation and Internationalization in Small and MediumSized Enterprises," Journal of Small Business Management, 46 (4), 485-511.

Barson, D. C. (2010). "Technology, Science and Beauty Innovation," Global Cosmetic Industry Magazine, 17-19.
Becerra Rodríguez, F. \& Naranjo Valencia, J. C. (2008). "La Innovación Tecnológica en el Contexto de los Clusters Regionales," Cuadernos de Administración Bogotá 21 (37), 133-159.

Beise-Zee, R. \& Rammer, C. (2006). "Local User-Producer Interaction in Innovation and Export Performance of Firms," Small Business Economics 27, 207-222.

Bernstein Research, (2009). LVMH: The King of the Luxury Jungle, Hong Kong: Bernstein Research.

Bhaskaran, S. (2006). "Incremental Innovation and Business Performance: Small and Medium-Size Food Enterprises in a Concentrated Industry Environment," Journal of Small Business Management, 44 (1), 64-80.

Björk, J., Boccardelli, P. \& Magnusson, M. (2010). "Ideation Capabilities for Continuous Innovations," Creativity and Innovation Management 19 (4), 385-396.

Census, (2000). Población por Edad y Sexo Municipio de Mayaguez. [online] Available at: http://209.68.12.238/censo2000/municipio s.php?municipio=MY. [Accessed 3 December 2012].

Chiu, Y. T. H. (2009). "How Network Competence and Network Location Influence Innovation Performance," Journal of Business \& Industrial Management 24 (1), 46-55.

Doran, J. \& O'Leary, E. (2011). "External Interaction, Innovation and Productivity: An Application of the Innovation Value Chain for Ireland," Spatial Economic Analysis 6 (2), 199 - 222.

Dr. Víctor, A. Orengo Serra Foundation, Inc. (2005-2010). Bill of lading, Universal Forwarding Co. San Juan: Dr. Víctor A. Orengo Serra Foundation, Inc.

Dr. Víctor, A. Orengo Serra Foundation, Inc. (2008). Informe de Situación y Proyecciones: Línea de Productos de Estética Casmara S.A. 
19 Journal of Innovation Management in Small \& Medium Enterprise

San Juan: Dr. Víctor A. Orengo Serra Foundation, Inc.

Eurocontrol Inc, (1996). Price List. Eurocontrol, Inc.

EuroImpact Trade Show (2004). Exhibitors. Miami: EuroImpact.

Francés Simón, Ana., (2010). Informe de Ferias de la Oficina Económica de la Embajada de España en Milán. Milan: Cosmoprof Worldwide.

Gulati, R. (1999). "Network Location and Learning: The Influence of Network Resources and Firm Capabilities on Alliance Formation," Strategic Management Journal, 20, 397-420.

Hansen, M. T. \& Birkinshaw, J. (2007). "The Innovation Value Chain," A Logic for Fixing Your Company's Innovation Problems, Harvard Business Review 85 (6), 121-130.

Hao, G. (2005). 'Supply Chain Coordination with Asymmetric Information,' The Business Review Cambridge, 3 (2), 167-171.

ICEX-Cosmoprof Bologna, (2010). 'Spanish Cosmetics: A Wide Range of Exclusive,' Quality Products. Bologna, ICEX-Cosmoprof Bologna.

Isaksen, S. G. \& Ekvall, G. (2010). "Managing for Innovation: The Two Faces of Tension in Creative Climates," Creativity and Innovation Management 19 (2), 73-88.

Johannessen, J.- A., Olsen, B. \& Lumpkin, G. T. (2001). "Innovation as Newness: What is New, How New, and New to Whom?," European Journal of Innovation Management, 4 (1), 20-31.

Kara, A., Spillan, J. E. \& DeShields, O. W. (2005). "The Effect of a Market Orientation on Business Performance: A Study of SmallSized Service Retailers Using MARKOR Scale," Journal of Small Business Management, 43(2), 105-118.
Keskin, H. (2006). "Market Orientation, Learning Orientation, and Innovation Capabilities in SMEs," European Journal of Innovation Management, 9 (4), 396-417.

Kline, S. J. \& Rosenberg, N. (1986). "An Overview of Innovation," In: R. Landau, (Ed.), The Positive Sum Strategy: Harnessing Technology for Economic Growth, National Academy Press, pp. 275-306.

Kotler, P. \& Lane, K. (2006). Marketing Management 12e, Pearson, Prentice-Hall.

Kuratko, D. F. \& Hodgetts, R. M. (2004). 'Entrepreneurship: Theory, Process and Practice,' Thompson South-Western.

Lumpkin, G. T. \& Dess, G. G. (1996). "Clarifying the Entrepreneurial Orientation Construct and Linkin It to Performance," The Academy of Management Review 21 (1), 135172.

Naver, J. C. \& Slater, S. F. (1990). "The Effect of a Market Orientation on Business Profitability," Journal of Marketing 20-35.

Newman, M. \& Zhou, Y. (2008). "The Process of Enterprise Resource Planning Implementation and Business Process Reengineering: Tales from two Chinese Small and Medium-Sized Enterprises," Information System Journal 18, 405-426.

Pulkkanen, R., Lintuiemi, M. \& Harmaakorpi, V. (2005). 'Entrepreneurial Demand and Regional Response in Building Innovative Capability in SMEs,' Proceeding of Entrepreneurship Symposium Conference the Entrepreneur-Innovation-Marketing Interface, Karlsruhe, Germany, 2005.

Renko, M., Carsrud, A. \& Brannback, M. (2009). "The Effect of Market Orientation, Entrepreneurial Orientation and Technological Capability on Innovativeness: A Study of Young Biotehcnology Ventures in the United States and in Scandinavia," Journal of Small Business Management, 47 (3), 331369. 
Roper, S., Du, J. \& Love, J. H. (2008). "Modeling the Innovation Value Chain," Research Policy, 37 (6-7), 961-977.

Rothgang, M. \& Trettin, L. (2005). "Patterns and Determinants of Innovation in the German Craft Sector," Proceeding of the Entrepreneurship Symposium Conference the Entrepreneur-Innovation-Marketing Interface, Karlsruhe, Germany, 2005.

San Juan Beauty Show (2005). Lista de Expositores. San Juan: San Juan Beauty Show.

San Juan Beauty Show (2010). Lista de Expositores. San Juan: San Juan Beauty Show.

Shao, Y., Chen, S. \& Cheng, B. (2008). "Analyses of the Dynamic Factors of Cluster Innovation, A Case Study of Chengdu Furniture Industrial Cluster," International Management Review, 4 (1), 51-59.

Tolstoy, D. (2009). "Knowledge Combination and Knowledge Creation in Foreign-Market Networks," Journal of Small Business Management, 47 (2), 202-220.

Verhees, F. J. H. M. \& Meulenberg, M. T. G. (2004). "Market Orientation, Innovativeness, Product Innovation, and Performance in Small Firms," Journal of Small Business Management 42 (2), 134-154.

Wang, L. \& Kess, P. (2006). "Partnering Motives and Partner Selection: Cases studies of Finnish Distributor Relationships in China," International Journal of Physical Distribution \& Logistics Management 36 (6), 466-478.

Wheelen, T. L. \& Hunger, J. D. (2008). 'Strategic Issues in Entrepreneurial Venture and Small Business, Strategic Management and Business Policy,' Pearson Prentice-Hall, Upper Saddle River, NJ.

Wolff, J. A. \& Pett, T. L. (2006). "Small-Firm Performance: Modelating the Role of Product and Process Improvements," Journal of Small Business Management 44 (2), 268-284.
Yin, R. K. (1998). "The Abridged Version of Case Study Research: Design and Method," In L. Bickman, L. and D.J. Rog, (Ed.), Handbook of Applied Social Research Methods, Thousand Oaks: Sage Publications, pp. 229259.

Zain, M. \& Ng, S. I. (2006). "The Impacts of Networks Relationships on SMEs Internationalization Process," Thunderbird International Business Review 48 (2), 183205. 